Victoria Nazarevich,

PhD (Candidate of Psychological Sciences), associate professor,

Rivne State University of Humanities, 12, Stepana Bandera Str., Rivne, Ukraine

\title{
ORGANIZATION OF COMMUNICATION SYSTEM \\ IN THE EDUCATIONAL ENVIRONMENT WITH SIGNS OF OSTRACISM
}

The article examines the system of organizational principles of communication in the educational environment with manifestations of ostracism and the influence of ostracizing tendencies in school groups on the academic and social development of students and the professional achievements of teachers. The peculiarities of the communication system formation in educational institutions are analyzed. It is determined that the administration of the educational institution and the teaching staff acts as a catalyst both in the formation of cooperative relations and in the implementation of educational work of the school unit. The aim of the study was to carry out a theoretical analysis of organizational aspects of communication systems in the educational environment with signs of ostracism. The structure of conditions for ecological communication in the educational system was formed: participants feel safe, the presence of an atmosphere without grading during the educational process, a sense of warmth, active interest in students, the compassion of adults, no corporal punishment in case of violation of rule or other unacceptable behaviour. Such general scientific theoretical methods of information study as analysis, synthesis, abstraction, generalization, induction, deduction, explanation and classification were used to achieve the aim of the study. Risk factors that affect the success of interpersonal interaction are revealed: a number of external factors, such as natural phenomena or social events (conflict, change of collective, disturbance of the structure of educational space - change of leader), or internal factors, such as the behaviour of teachers and staff, number of students, group composition, entry of new persons into an already formed group, an accident in the group, etc. The classification of Marshall factors that affect communication during the learning space is included: the number and quality of interactions between adults and students; learning environment, including buildings, classrooms, available materials, as well as the perception of this space by teachers and students; student's success; the presence of an atmosphere of equality between all subjects of educational activity. The role of the management personnel in the process of creating an ecological educational space is indicated, because the communication skills of the administration of the institution largely determine the effectiveness of the educational space and the achievement of goals. The characterological features of the administration are reflected, which are a manifestation of a high level of emotional intelligence, as a consequence of possibility of building an effective system of communicative ties: self-awareness, empathy, social responsibility, focus on reality, sociability, control of impulses.

Keywords: communication system, communication, ecological communication, interpersonal interaction, pedagogical collective, signs of ostracism.

Подано до редакиії 17.11.2021

УДК: 004.855.3:[613.86-057.87:37.091.2]:614.44

DOI: https://doi.org/10.24195/2414-4665-2021-4-3

Олексій Чебикін,

доктор психологічних наук, професор, дійсний член НАПН України,

Державний заклад «Південноукраӥнський наџіональний педагогічний університет імені К. Д. Уиинського», вул. Старопортофранківська, 26, м. Одеса, Україна, ORCID ID: https://orcid.org/0000-0001-7905-2708

\section{КОНЦЕПТУАЛЬНІ ПІДХОДИ МОЖЛИВОСТЕЙ ДОСЛІДЖЕННЯ ОСНОВ ЕМОЦЙНОГО ЗДОРОВ'Я УЧАСНИКІВ НАВЧАЛЬНОЇ ДІЯЛЬНОСТІ В УМОВАХ КОРОНАВІРУСНОӤ ПАНДЕМІЇ}

У статті розглядаються можливості вивчення психологічних основ емоиійного здоров'я осіб, задіяних в навчальну діяльність в умовах пандемії COVID-19. Показано, щзо психологічні основи емоційного здоров'я тривалий час побічно вивчалися в рамках проблеми психічного здоров'я. В останні роки розиирилися дослідження, де самостійно предметом стають різні аспекти емочійного здоров'я. Проте нерідко здійснюються спроби розкрити його зміст, лише спираючись на окремі ознаки, такі як тривожність, агресивність та ін. До того ж є неоднозначні підходи до його розуміння як суто психологічного феномену. Процес пізнання иього явища показав, щчо особливої важливості в сучасних умовах набуває проблема емоційного здоров'я студентів та педагогів 
в умовах карантинних обмежень через коронавірусну епідемію та його відновлення після иієї хвороби. Узагальнено деякі фактори впливу карантинних обмежень на емочійне здоров'я. При изьоу фіксуються як позитивні, так і негативні тенденції в його прояві. Відзначено, щзо проблема психологічних основ емоційного здоров'я різних осіб, залучених до навчальної діяльності в умовах коронавірусної пандемії, незважаючи на ї̈ актуальність для теорії і практики сучасної психології, залишається недостатньо вивченою. У представлених дослідженнях нами емочійне здоров'я розглядається як специффічне оцінне суб'єктивне відображення функціонування почуттєвоі сфери у людини від відносно позитивно-комфортного до негативно-дискомфортного стану в різних умовах ї̈ життєдіяльності. На основі виконаної роботи побудовано умовну концептуальну модель комплексного дослідження психологічних основ емочійного здоров'я, в змісті якої провідними виступили такі компоненти, як: фактори впливу, ознаки прояву, змістові характеристики, профілактичні та корекційні засоби. Отримано попередні емпіричні дані відносно особливостей емочійного здоров'я в осіб через 60 днів з моменту початку хвороби на COVID-19. Виділено специцічні ознаки емоційної сфери, щзо характеризують осіб, які перенесли стрес в легкій, середній та складній формах. Показано, що ті, хто його перенесли в складній та середній формах через 60 днів фактично не відновили стан емоційного здоров'я. Що стосується тих, хто мав легку його форму прояву, то у них відмічені тенденції до відновлення стану емоційного здоров'я.

Ключові слова: емоційне здоров'я, фактори, стреси, властивості, стани, компоненти, концептуальна модель, COVID-19.

\section{блеми}

Вступ та сучасний стан досліджуваної про-

Виклики, які постали перед людством на початку XXI ст. не тільки ускладнили, а й інтенсифікували емоційну діяльність людей в умовах прискорених інформаційних, глобалізаційних процесів, де на тлі військових конфліктів, які не припиняються, екологічних і техногенних катастроф, економічних криз, загострення політичної боротьби за природні і енергетичні ресурси землі та ін. На сьогодні до різних складних обставин ще додалася глобальна пандемія (COVID-19), що охопила і продовжує поширюватися на сотні держав з великими людськими жертвами.

Введення тривалих карантинних обмежень, пов'язаних з погіршенням умов життя людей, позбавленням їх доступу до традиційної, трудової, навчальної, культурної, спортивної та інших видів діяльності, погіршенням матеріального забезпечення існування не могло не відбитися на їх емоційних станах. Вчені різних країн, лікарі, психологи, соціальні працівники, журналісти щодо цього констатують численні збільшення різних стресів, сімейних конфліктів, суїцидальних проявів. Значна кількість людей виявилася психологічно неготовою до перебування в таких карантинних умовах тривалий час. До цього слід додати, що не всі державні інститути на необхідному рівні підтримали населення в цих умовах життєдіяльності. Загострює проблему ще й те, що значна частина людей порушують карантинні умови.

Водночас різні інформаційні джерела відзначають, що поряд 3 емоційно негативними проявами фіксуються і позитивні у населення в період карантину. Останні умовно можна охарактеризувати як взаємопротилежні за своєю емоційною спрямованістю (табл. 1).

\section{Таблиця 1}

Узагальнення як негативних, так і позитивних емоційних проявів відзначаються у людей в обмежених умовах карантину, ще викликані COVID-19

\begin{tabular}{|l|l|}
\hline \multicolumn{1}{|c|}{ Позитивні } & \multicolumn{1}{|c|}{ Негативні } \\
\hline - Формування установок на управління емоційним & - Прояв психічних емоційних станів на рівні триво- \\
здоров'ям. & жності, конфліктності, фрустрації, депресії, різних \\
- Пошук і використання різних фізичних вправ, & дискомфортних настроїв, почуттів і активності. \\
прийомів, тренінгів для поліпшення емоційного & - Підвищення емоційної сензитивності до різних \\
стану. & стресових, а також постстресових факторів і станів. \\
- Пошук і використання психологічних прийомів, & - Виникнення емоційної інтернет-залежності. \\
орієнтованих на створення емоційно комфортних & - Прояв емоційного дискомфорту від збільшення \\
сімейних відносин і подолання конфліктів. & ваги. \\
- Використання емоційно-вольових зусиль, орієнто- & - Прояв емоційної нестійкості в подоланні сімейних \\
ваних на внесення корективів в поточні та перспек- & конфліктів. \\
тивні особистісні цілі і плани. & - Прояв ознак неадекватної самооцінки на тлі емо- \\
- Переосмислення власних емоційно-позитивних & ційної напруги \\
цінностей. & - Прояв емоційної виснажливості від тривоги і обме- \\
- Поліпшення емоційно-духовного розвитку за раху- & жень та ін. \\
нок читання книг, перегляду фільмів та ін. & \\
- Емоційна активація мотивації в певних умовах на & \\
досягнення життєвих цілей та ін. & \\
\hline
\end{tabular}


Особливо слід відзначити, що карантинні обмеження, що пов'язані з переходом в різних освітніх установах студентів на дистанційну форму навчання, також негативно впливають на їх емоційні особливості внаслідок соціального обмеження невідкладних і властивих їм комунікативних і рухомих дій. Фіксовані при цьому емоційні зміни у студентів в таких умовах ще вимагають поглибленого їх вивчення в аспекті того, наскільки вони стійкі, в якому співвідношенні вони мають місце в залежності від статі, віку, особистісних особливостей і умов навчальної діяльності. На жаль, у багатьох державних інститутах у цих умовах побачили можливість зменшення фінансових ресурсів, спираючись лише на окремі позитивні моменти дистанційної iï форми, ігноруючи численні негативні. Цю позицію активно підтримують різні інформаційні компанії, що зацікавлені в розширенні своїх послуг.

Відомо, що надмірне використання різних гаджетів, без урахування умов емоційної регуляції навчальної діяльності при їх застосуванні, веде не тільки до стресогенності в таких умовах, але ще й до певної емоційної залежності і домінування звужених основ пізнавальної діяльності. 3 огляду на масштаби такого становища, актуальним $\epsilon$ проведення спеціальних досліджень не тільки з метою вивчення небажаних особливостей в прояві емоційного здоров'я, а й пошуку корекційних та профілактичних заходів його поліпшення.

Всі ці та інші обставини не могли не загострити проблему емоційного здоров'я багатьох людей. Вiдомо, що фрагментарно окремі аспекти психологічних основ емоційного здоров'я тривалий час досліджувалися побічно в межах проблем психологічного здоров'я. Лише в останні кілька років з'явилися роботи (Чіа, Саксер, 2012; Тарабакіна, 2015; Фаустова, Комлік, 2019; Кічук, 2019 та ін.), де робляться спроби, в яких безпосередньо предметом дослідження виступають різні особливості саме емоційного здоров'я на основі аналізу проявів тривожності, агресії, певних властивостей емоційної зрілості та ін.; спостерігається пошук використання різних психологічних технологій, що впливають на поліпшення емоційного здоров'я та ін. У цьому аспекті проглядаються неоднозначні погляди щодо специфіки змісту емоційного здоров'я як суто психологічного феномена. Наявність таких обмежених підходів аналізу психологічних механізмів, що лежать в основі прояву емоційного здоров'я, ускладнює процес пізнання цього феномену. Крім того, методологічні основи опису змісту і специфіки прояву емоційного здоров'я переважно носять вузькоспрямовані підходи, які не дозволяють його досліджувати як цілісне явище. Крім того, фактично невивченою залишається проблема емоційного здоров'я осіб, які перехворіли на коронавірус та проходили лікування.

\section{Мета дослідження}

Узагальнення різних поглядів щодо проблеми психологічних основ емоційного здоров'я спонукало нас до мети про необхідність побудови концептуальної моделі його комплексного дослідження в осіб, які пе- рехворіли на COVID-19. При цьому ми виходили 3 припущення, що тільки спираючись на цілісність, можемо вивчати емоційне здоров'я як явище, враховуючи різні його ознаки психологічного порядку.

\section{Результати дослідження}

Під емоційним здоров'ям ми розглядаємо специфічне оцінне суб'єктивне відображення функціонування почуттєвої сфери людини від іiі відносно позитивно-комфортного до негативно-дискомфортного в різних умовах iii життєдіяльності. Прямими специфічними ознаками його може виступати широкий спектр різних психологічних особливостей функціонування емоційної сфери людини. Останні за вираженістю можна представити у вигляді умовної шкали від максимального адаптивно-комфортного (оптимістичного) до відносно негативно-дискомфортного, що може проявлятися у вигляді тих чи інших відхилень як на ситуативному, так і відносно стійкому рівнях.

У результаті проведених досліджень по узагальненню як прямих, так і опосередкованих доступних даних, побудовано умовну концептуальну модель дослідження психологічних основ емоційного здоров'я, яка складається з чотирьох відповідних компонентів (рис. 1).

Перший компонент (фактори впливу) у своєму змісті відображає стреси, що впливають на емоційне здоров'я людини у різних умовах діяльності. Тут до особливого класу нами віднесені стреси, що виникають від різних соціальних умов (деструктивних, екстремальних / дериваційних, монотонних, депресивних, психогенних обставин, в тому числі катастроф, епідемій та ін.), які впливають на емоційне здоров'я. Стресові фактори впливу можуть бути не тільки ті, що наведені, а також ще від неспроможністі задоволення основних потреб, що забезпечують життєдіяльність, погіршення екологічних умов, надмірних фізичних навантажень, незадовільних сімейних, навчальних, трудових умов діяльності, виникнення різних хвороб, залежностей та ін. Отже, вивчаючи різні показники в змінах емоційного здоров'я, важливо паралельно аналізувати більш цілісно причинно-наслідкові умови стресів, які можуть впливати на його стан. Усвідомлюючи, що пізнання емоційного здоров'я може паралельно ще досліджуватися на неврологічному, психіатричному та інших рівнях в межах вказаних галузей наукових знань, які мають притаманні саме ним свій предмет дослідження на відміну від психологічного. Однак це не виключає можливості використання знань інших наук при вивченні психологічних особливостей емоційного здоров'я. В окремих випадках, а іноді в обов'язковому порядку, опора на такі дані дозволяє при необхідності розширити коло інших важливих його детермінантів в поєднанні $з$ психологічними, а також підбирати і розробляти на цій основі стратегії його відновлення. Саме такий цілісний підхід діагностики особливостей емоційного здоров'я, на нашу думку, дозволить більш адекватно його характеризувати та визначати засоби профілактики та корекції. 


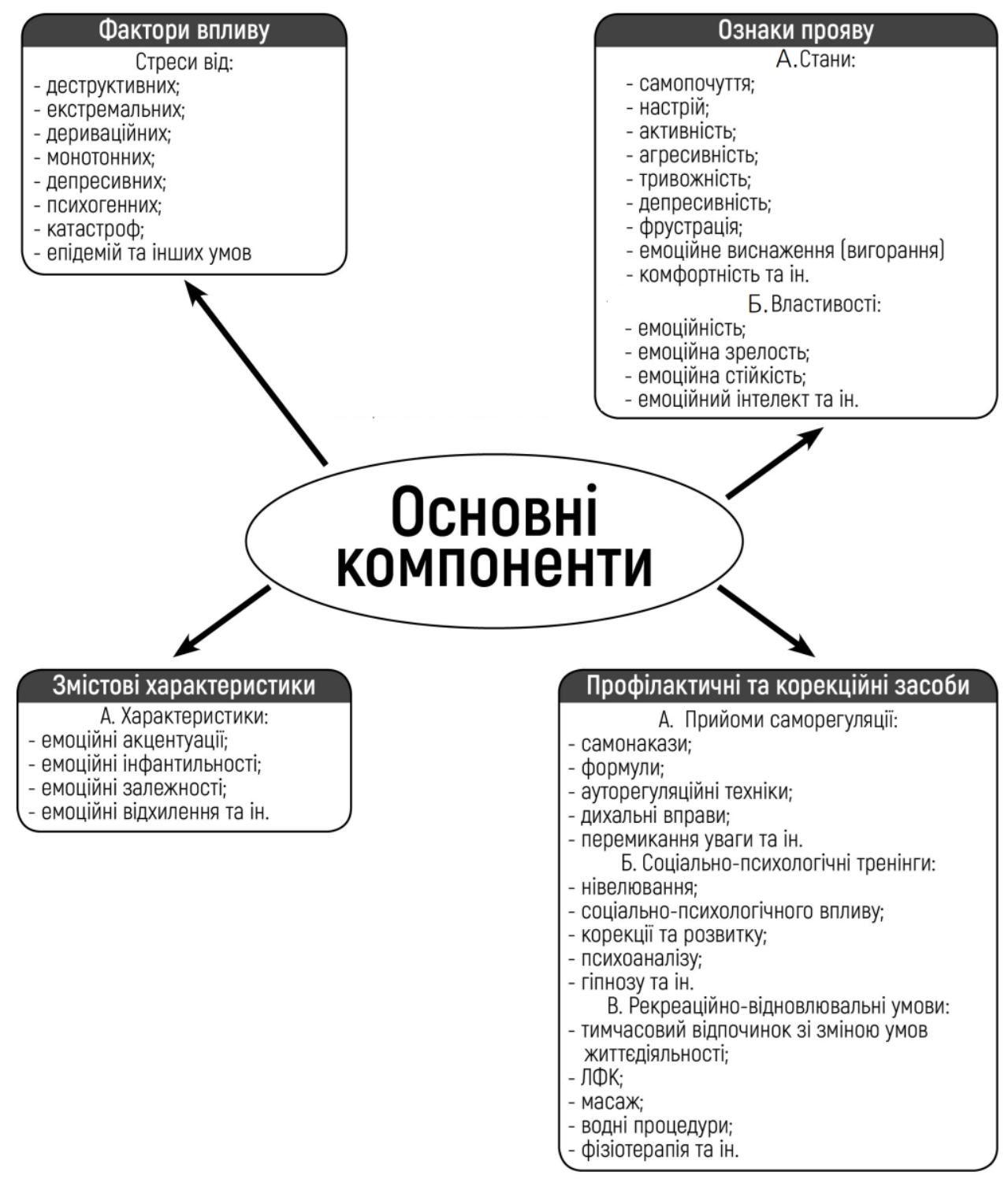

Рис. 1. Концептуальна модель дослідження психологічних основ емоиійного здоров'я

Другий компонент (ознаки прояву) відображає специфічні властивості та стани, що характеризують емоційне здоров'я. До одного з них ми віднесли: емоційність, емоційну стійкість, емоційну зрілість, емоційний інтелект та ін. До другого - емоційне виснаження, самопочуття, настрій, активність, агресивність, тривожність, емоційну амбівалентність, депресивність, фрустрацію, страх та ін.

До третього компоненту (змістові характеристики) нами віднесені такі особливості емоційного здоров'я, як: емоційні акцентуації (емоційна інфантильність чи гіперактивність), емоційні залежності, емоційні відхилення та ін.

Четвертий компонент названий нами як профілактично-корекційні засоби, що включає: по-перше, психологічні прийоми; по-друге, соціально-психологічні тренінги; по-третє, різні рекреаційно-відновлювальні умови.

На нашу думку, такі концептуальні позиції відкривають можливості для дослідження різних специфічних ознак емоційного здоров'я та опису його характеристик.

Перевага запропонованої концептуальної моделі пізнання основ емоційного здоров'я в тому, що вона дозволяє: по-перше, розглядати в якості його предмета дослідження різні його ознаки як психологічного феномена; по-друге, підійти до пізнання ознак емоційного здоров'я більш цілісно, системно і комплексно; по-трете, здійснювати оцінку даних різних складових емоційного здоров'я поетапно з урахуванням їх психологічного розвитку та особливостей прояву. Ми не виключаємо, що запропонований підхід в процесі подальшої роботи може змінюватися та доповнюватися.

Спираючись на викладені теоретичні уявлення ми 
поставили завдання провести пошукове попереднє емпіричне обстеження особливостей емоційного здоров'я осіб, які хворіли на COVID-19 після 60 днів від іiі початку. За різними даними саме такий період фахівці відмічають як відносно необхідним для відновлення стану здоров'я. Маються чисельні дані, що процес його відновлення після завершення інтенсивного клінічного лікування є різним за тривалістю, в ході якого у людей спостерігаються чисельні небажані побічні симптоми в особливостях здоров'я. На протязі такого відновлювального періоду та по його закінченню різні ознаки емоційного здоров'я можуть виступати найбільш інформативними показниками, що супроводжують цей процес.

Враховуючи наведене, нами здійснювалось комплексне обстеження осіб, які піддавалися стресу на COVID-19 у легкій, середній та складній формах. При визначенні методології дослідження спирались на представлену вище концептуальну модель лише окремих компонентів пізнання емоційного здоров'я. Основні зусилля були зосереджені на трьох ії компонентах: по-перше, факторах впливу, що відображали особливості пережитого стресу; по-друге, компоненті ознаків прояву, що характеризував специфічні властивості та стани емоційного здоров'я; по-третє, змістових характеристик емоційного здоров'я.

\section{Методи дослідження}

Для дослідження був обраний поширений комплекс методик, а саме: «Фрайбурзький особистісний опитувальний FPI» в адаптації та модифікації А. О. Крилова та Т. І. Ронгінської; Анкета «САН» Доскіна В. А., Н. А. Лаврентьєвої, В. Б. Шарай та М. П. Мірошнікова; методика «Диференціальної діагностики станів» (В. А. Смуров); методика «Визначення стресостійкості та соціальної адаптації» Т. Холмса та Р. Раге; опитувальник «Подолання важких життєвих ситуацій SVF120» В. Янке та Г. Єрдмана в адаптації рі- вня суб'єктивного відчуття самотності Д. Рассела та М. Фергюссон; методика «Визначення емоційної стійкості» В. В. Суворова. При цьому в якості показника, що характеризував стресогенні умови, використовувалась умовна шкала рівня пережитого стресу при хворобі на COVID-19 в легкій, середній та складній форMax.

Вказані методики дозволили виявити та кількісно оцінити рівень прояву різних емоційних властивостей та станів здоров'я відповідно наведеним компонентам та за такими показниками: П1 - рівень складності пережитого стресу при хворобі на COVID-19; П2 - емоційне виснаження; П3 - невротичність; П4 - депресивність; П5 - спонтанна, П6 - реактивна агресія та П7 ії загальний показник; П8 - дратівливість; П9 - емоційність; П10 - емоційна лабільність; П11 - уникнення стресу; П12 - стресостійкість; П13 - емоційна обізнаність; П14 - емоційний інтелект; П15 - управління власними емоціями; П16 - розпізнавання емоцій; П17 самопочуття; П18 - активність; П19 - настрій.

Загальну вибірку обстежених склали 69 викладачів та студентів у віці від 19 до 55 років, яка дозволила розподілити всіх обстежених за трьома вимірами пережитого стресу: в легкій формі - 20 осіб, у середній чи помірній формах - 23 особи та в складній - 16 осіб.

Зважаючи на отримані попередні дані можна побачити, що значення показників, які характеризували різні ознаки емоційного здоров'я при хворобі на COVID-19 після 60 днів, фіксують як спільні, так і відмінні тенденції в їх прояві. У тих, хто пережив стрес у складній формі ще відмічається, з одного боку, підвищене емоційне виснаження, невротичність, депресивність, дратівливість, а 3 іншого - понижена емоційна лабільність, уникнення стресу та стресостійкість, емоційна обізнаність, емоційний інтелект, активність, самопочуття та настрій (рис. 2).

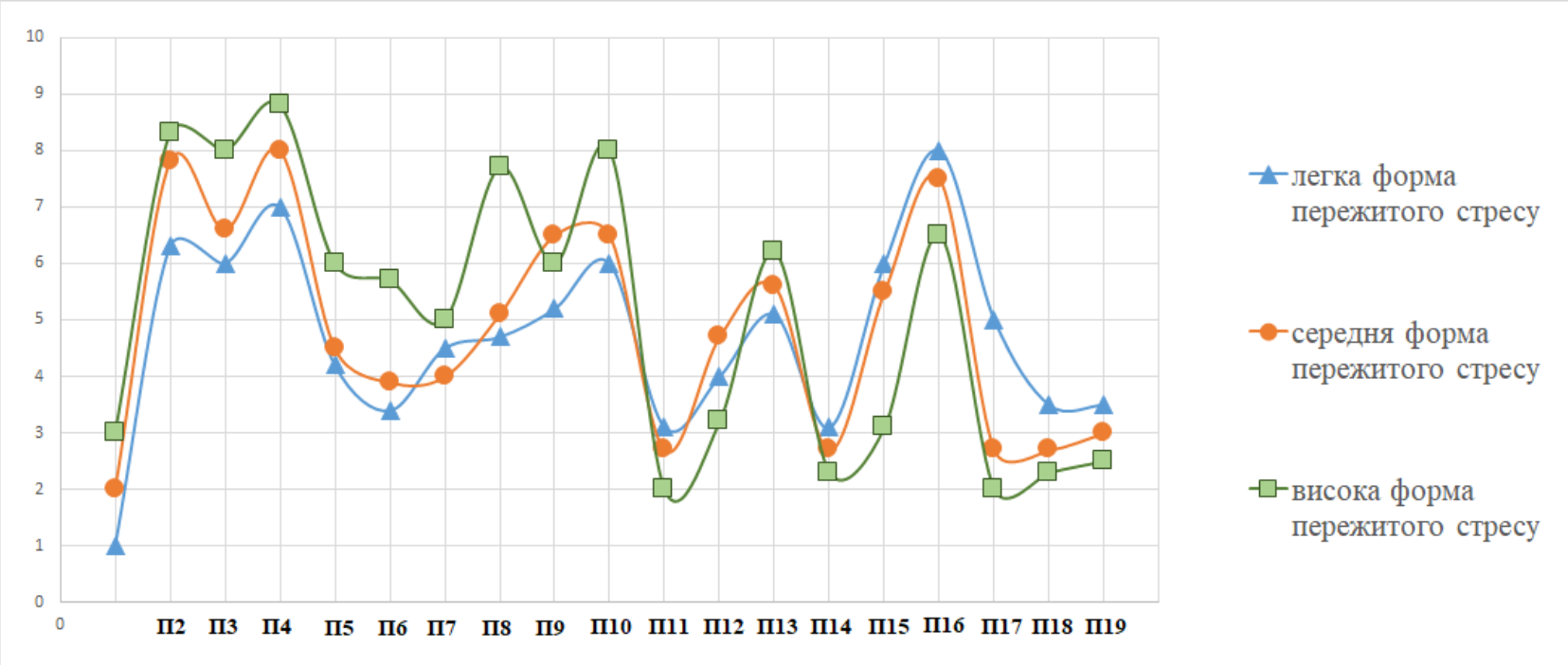

Рис 2. Середні значення показників, щуо характеризують різні ознаки емоційного здоров'я осіб в залежності від пережитого стресу при хворобі на COVID-19 
У переважній більшості наведені показники за аналогічною тенденцією маються у тих, хто пережив такий стрес в середній формі, але незначним зменшенням їх прояву.

$\mathrm{Ti}$, у кого була легка форма прояву стресу, дані значення фіксувалися на відносно нормативному рівні (агресивність, дратівливість, емоційність, розпізнавання емоцій, а також самопочуття, активність і настрій), а інші знаходилися в межах прояву як в двох попередніх групах.

Наведені результати свідчать, що період відновлення стану емоційного здоров'я у тих, хто пережив стрес в складній і середній формах через 60 днів ще не завершився.

Вірогідно у вказаних осіб на ускладнення відновлення стану емоційного здоров'я почали діяти стресфактори, які виникли в процесі хвороби як-то втрати нюху, зниження температури тіла, погіршення різних видів пам'яті та ін.

Якщо говорити про осіб, які пережили стрес в легкій формі на COVID-19, то тут маються певні тенденції до відновлення емоційного здоров'я від попередніх.

Що стосується комплексу найбільш інформативних показників, які фіксували небажані прояви в ознаках емоційного здоров'я, до нього можна віднести: емоційне виснаження, депресивність, невротичність, емоційний інтелект та ін. Очевидно, що останні повинні стати предметом поглибленого аналізу та вивчення в комплексі з різними особистісними особливостями для організації адекватних умов та профілактики цієї хвороби.

Наведені результати на обмеженій вибірці тих, хто перехворів на COVID-19 за різними формами, $є$ попередніми даними, які можуть лише засвідчувати певні тенденції у станах емоційного здоров'я. Водночас такі результати виступають підставою для проведення в подальшому більш поглиблених досліджень 3 урахуванням вікових, гендерних та інших відмінностей.

\section{Висновки}

Узагальнюючи наведені теоретичні уявлення та емпіричні дані щодо дослідження психологічних основ емоційного здоров'я різних осіб, задіяних в навчальний процес в умовах коронавірусної пандемії, можна зробити попередні висновки:

1. Показано, що загалом проблема психологічних основ емоційного здоров'я є достатньо актуальною

\section{Література}

1. Кічук А. В. Емоційно-особистісні особливості психологічного здоров'я студента у психологічному дискурсі. Наука і освіта. 2019. №1. С. 45-51.

2. Мантэк Чиа, Дина Саксер: Эмоциональное здоровье: Трансформация отрицательных эмоций в жизненную силу. Перевод с анг. Гончарова. Москва: ООО Издательство «София», 2012. 224 с.

3. Тарабакина Л. В. Эмоциональное здоровье как предмет социально-психологических исследований. Теория и практика общественного развития. Краснодар, 2015. №8. С. 250-252.

4. Фаустова И. В., Комлик Л. Ю. К вопросу эмоционального здоровья современных детей старшего як в теоретичному, так і практичному аспектах в сучасній психології. В першому випадку ще недостатньо розкриті специфічні психологічні механізми та ознаки цього феномену, який нерідко ототожнюються 3 іншими психологічними явищами. Останнє ускладнює визначення адекватних методів його діагностики та корекції.

2. Показано, що емоційне здоров'я може розглядатися як специфічне оцінне суб'єктивне відображення функціонування почуттєвої сфери людини від її відносно позитивно-комфортного до негативно-дискомфортного стану в різних умовах іiі життєдіяльності.

3. Відмічено, що карантинні обмеження учасників навчальної діяльності при пандемії на COVID-19 можуть обумовлювати у них як позитивні, так і негативні емоційні прояви.

4. Побудовано умовну концептуальну модель комплексного дослідження психологічних основ емоційного здоров'я, в змісті якої провідними виступили такі компоненти, як: фактори впливу, ознаки прояву, змістові характеристики, а також профілактичні та корекційні засоби.

5. Опора на окремі компоненти запропонованої концептуальної моделі дозволила в пошукових емпіричних дослідженнях показати, що особи, які піддавались стресу при хворобі на COVID-19 в складній та середній формах через 60 днів ще не відновили стан свого емоційного здоров'я. Навпаки ті особи, які перенесли його в легкій формі, тобто піддавшись незначному стресу за вказаний період, за окремими діагностованими показниками вже мали значення, які вказували на певні позитивні тенденції відновлення їх емоційного здоров'я.

Вказані результати можуть свідчити, що для тих, хто пережив стрес в складній та середній формах цей період відновлення їх емоційного здоров'я ще потребує часу, а також профілактичних та корекційних засобів. Що стосується тих, хто мав легку форму, то тут очевидно що період теж ще не завершився, але він зрушився.

Перспективним на майбутнє виступає необхідність проведення дослідження зі стану емоційного здоров'я на більшій виборці осіб, які перехворіли на COVID-19 з урахуванням гендерних та вікових особливостей $з$ розширенням більш широкого комплексу методик та ін.

дошкольного возраста. Психология образования в поликультурном пространстве. Елец: Елецкий государственный университет им. И.А. Бунина, 2019. №4(48) C. 39-46.

\section{References}

1. Faustova, I. V., Komlik, L. Yu. (2019). K voprosu emotsionalnogo zdorovya sovremennykh detey starshego doshkolnogo vozrasta [The issue of emotional health of modern children of senior preschool age]. Psikhologiya obrazovaniya v polikulturnom prostranstve - Psychology of education in a multicultural space, 4 (48). S. 39-46. Yelets: Yelets State University named after I. A. Bunin.

2. Kichuk, A. V. (2019). Emotsiino-osobistisni 
osoblivosti psikhologichnoho zdorovia studenta $\mathrm{u}$ psikhologichnomu diskursi [Emotional and personal features of psychological health of the student in psychological discourse]. Nauka i osvita - Science and Education, 1, 45-51 [in Ukrainian].

3. Mantak, Chia; Dena, Saxer (2012). Emotsionalnoe zdorovie: Transformatsiya otritsatelnykh emotsiy $v$ zhiznennuyu silu [Emotional Health: Transforming Negative Emotions into Life Force]. Goncharova (Transl.).
Moscow: Publishing House "Sofia" LLC [in Russian].

4. Tarabakina, L. V. (2015). Emotsionalnoe zdorovie kak predmet sotsialno-psikhologicheskikh issledovaniy [Emotional health as a subject of socio-psychological research]. Teoriya i praktika obshchestvennogo razvitiya Theory and practice of social development, 8, 250-252. Krasnodar [in Russian].

\author{
Oleksiy Chebykin, \\ Doctor of Psychological Sciences, professor, \\ full member of the NAES of Ukraine, \\ The State Institution "South Ukrainian National Pedagogical University named after K. D. Ushynsky", \\ 26, Staroportofrankivska Str., Odesa, Ukraine
}

\title{
CONCEPTUAL APPROACHES TO THE POSSIBILITIES OF STUDYING THE EMOTIONAL HEALTH FOUNDATIONS OF PARTICIPANTS IN LEARNING ACTIVITY UNDER THE CORONAVIRUS PANDEMIC CONDITIONS
}

The article considers the possibilities of studying the psychological foundations of emotional health of people involved in learning activity under the COVID-19 pandemic conditions. It has been shown that the psychological foundations of emotional health have been indirectly studied for a long while in the context of mental health. The study has expanded in recent years, where various aspects of emotional health become the subject independently. The attempts, however, are often made to reveal its content only on the basis of certain features, such as anxiety, aggression, etc. There are furthermore the ambiguous approaches to its understanding as a purely psychological phenomenon. The cognitive process of this phenomenon has shown that the problem of emotional health of students and educators in quarantine restrictions due to the coronavirus epidemic and its recovery after this disease is of particular importance in modern conditions. Some factors of influence of quarantine restrictions on emotional health have been generalized. At the same time, both positive and negative tendencies in its manifestation are recorded. It has been noted that the problem of psychological foundations of emotional health of various people involved in learning activity under the coronavirus epidemic conditions, despite its relevance to the theory and practice of modern psychology, remains insufficiently studied. The emotional health was considered in the presented studies as a specific evaluative subjective reflection of the functioning of the sensory sphere in a person from a relatively positive-comfortable to a negative-uncomfortable state in different conditions of his/her life. On the basis of the performed work the Conditional Conceptual Model of Complex Study of Psychological Foundations of Emotional Health is constructed, in the maintenance of which such components as: factors of influence, signs of display, substantial characteristics, preventive and corrective means acted as leading ones. Preliminary empirical evidence on the characteristics of emotional health in individuals have been obtained in 60 days since the beginning of the COVID-19 pandemic. The specific features of the emotional sphere that characterize people who have experienced stress in mild, moderate and severe forms have been highlighted. It has been shown that those people who experienced it in severe and moderate forms in 60 days did not actually recover the emotional health. Those who had a mild form of it, they have tendencies to recover the emotional health.

Keywords: emotional health, factors, stresses, properties, states, components, conceptual model, COVID-19. 